すなわち，一般に， $\mathrm{Al}\left(\mathrm{C}_{2} \mathrm{H}_{5}\right)_{3-n} \mathrm{Cl}_{n}(n=0,1,1.5,2,3)$ を 触媒とするアセトアルデヒドの重合においては，モノマーと反応 しない条件下で重合した場合は（1）式のようなコンプレックス をつくり,プロトンによるカチオン重合をひき起して非晶性ポリ マーを与えると考えられる。しかしながら， $n=0$ すなわち、ト リエチルアルミニウムは反応性が大きいために変性をうけやすく， 変性により Al-OR 型の触媒を生成した場合, 配位アニオン重合 により結晶性の Al-OR アイソタクチックポリマーを与えると考 えられる。

$>$ Al-OR 型の触媒が配位アニオン重合をひき起こすことは, ト リエチルアルミニウムとアセトアルデヒド系, トリエチルアルミ ニウムとアルコール系の触媒が結晶性のポリマーを与えること， トリエチルアルミニウムと水系触媒でモノマーのアセトアルデヒ
ドと反応しない条件下では非晶性ポリマーを与え，モノマーと反 応する条件下では結晶性ポリマーを多く与えることから説明され る。

な拈トリエチルアルミニウムおよび，トリエチルアルミニウム 一水系触媒がルイス酸としての作用を有することは, 別に著者ら が行なった 4 員環および 5 員環の環状エーテル8) や, カチオン重 合性ビニルモノマーの重合")に拈いても認められている所であっ て, 本報のアセトアルデヒドの重合の結果はそれらの結果と一致 している。

8) 三枝, 今井, 古川, 高分子討論会（昭和 37 年 11 月, 大 阪）Makromol. Chem. 投稿中

9) 三枝, 今井, 古川, 日本化学会第 16 年会発表（昭和 38 年 4 月, 東京)

\title{
四塩化チタンートリェチルアルミニウム系触媒による 4-メチルペンテン-1の重合
}

(昭和 38 年 11 月 16 日受理)

新䄆*

\begin{abstract}
四塩化チタンートリエチルアルミニウム系触媒による 4-メチルペンテン-1 の重合をしらべた。重合条件と重合体のア

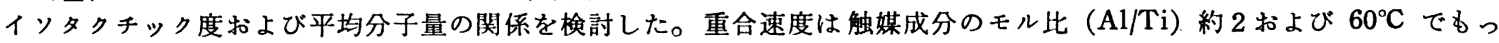
とも大きい。固体重合体中の $n$-ヘプタン不溶部の比率はモル比 $(\mathrm{Al} / \mathrm{Ti}) 1 \sim 6$ の範囲で小さいほど大きい。重合率 $x$ と 重合時間 $t$ の間には，触媒活性の時間的低下を考虑して導いた式 $\ln (1-x)=k\left(t_{0}{ }^{1 / 3}-t^{1 / 3}\right) \quad\left(t_{0}\right.$ : 触媒成分混合後重合開始までの時間, $k:$ 定数 $)$ が成立つ。触媒を $30^{\circ} \mathrm{C}$ で熟成することによって, 得られる重合体の $n$-ヘプタン可溶部の量が減少する傾向がある。
\end{abstract}

\section{1 腥 言}

分岐をもつ脂肪族の $\alpha$-オレフィンをZ Ziegler 型の触媒によっ て重合すると, $\alpha$-オレフィンの種類によっては結晶性の重合体が 得られ，融点は最高 $300^{\circ} \mathrm{C}$ 以上にも達することが知られている1。 これらの重合体のうちでポリ(4-メチルペンテン-1)がとくに注目 される主な理由は, 単量体がプロピレンの二量化によって比較的 容易に得られること，重合体の結晶性が良好であること，および 融点が $240^{\circ} \mathrm{C}$ 付近で溶融加工と成形後の製品の耐熱性とい5面か ら適当であると考学られるためであろう。Natta ら)はプロピレ ンをはじめて重合したのとほとんど同時に 4-メチルペンテン-1 の重合を行なっている。 Montecatini 社出願のベルギー特許 ${ }^{3)}$ に よると，三塩化チタンートリェチルアルミニウム系触媒で 54 70 ${ }^{\circ} \mathrm{C}$ で重合して得た重合体は $n$-ヘプタン不溶分 $24.5 \%$ を含み, この不溶部の融点は $200 \sim 205^{\circ} \mathrm{C}$ である。その後, Watt ${ }^{4)}$ は四 塩化チタンートリェチルアルミニウム系触媒を用い $40^{\circ} \mathrm{C}$ でこの単 量体の重合をしらべ四塩化チタンの量を一定とすると，モル比 $(\mathrm{Al} / \mathrm{Ti})$ が 1.5〜2 のときに重合率は最大となり，モル比が 1.0 付近で重合体中の $n$-ヘプタン不溶部の比率は最大になることを

* 東洋レーヨン株式会社中央研究所：大津市園山 3 丁目.

1) T. W. Campbell, A.C. Haven, Jr., J. Appl. Polymer Sci. 1, 73 (1959).

2) G. Natta et al., Chim. $e$ ind. (Milan) 38, 751 (1956).

3) Montecatini, Belg. P. 549, 891.

4) W. R. Watt, J. Polymer Sci. 45, 509 (1960),
認めた。また, Campbel15) は四塩化チタンーリチウムアルミニウ ムテトラデシル系触媒を用いて重合条件を検討し，へキセン-1 などとの共重合も行なっている。このほか 4-メチルペンテン-1 の重合については du Pont 社6) と U.C.C. 社 ${ }^{7)}$ の特許がある。 $\mathrm{du}$ Pont 社の特許によると, 周期律表 4 6 A 族の遷移金属の八 ロゲン化物，アルコキシ化合物またはアロキシ化合物，たとえば 四塩化チタン, 五塩化モリブデン, 塩化バナジルなどと金属水素 化物または金属アルキル化合物，たと音ばリチウムアルミニウム テトラアルキル, トリアルキルアルミニウム, グリニャール試薬 などとの組合わせが広い範囲にわたって 4-メチルペンテン-1 の 重合に有効であるとしている。Phillips 社のェチレン重合触媒で 4-メチルペンテン-1 を重合した例8) むあり，固体の重合体る得ら れるということであるが詳紼は明らかでない。

この報告では代表的な Ziegler 触媒として $\mathrm{TiCl}_{4}-\left(\mathrm{C}_{2} \mathrm{H}_{5}\right)_{3} \mathrm{Al}$ 系をえらび，4-メチルペンテン-1 の重合を検討した 結果につい て述べる。

\section{2 実 験 方 法}

\section{$2 \cdot 1$ 試 获}

4-メチルペンテン-1：分析值は次のと拈りである。

5) T. W. Campbell, J. Appl. Polymer Sci. 5, 184 (1961).

6) du Pont, 特公昭 34-5286.

7) U.C.C., 特公昭 34-8959.

8) A. Clark, et al., Ind. Eng. Chem. 48, 1152 (1956). 


\begin{tabular}{|c|c|}
\hline 成分 & $\mathrm{mol} \%$ \\
\hline 4-メチルペンテン-1 & 97.7 \\
\hline 4-メチルペンテン-2 & 1.9 \\
\hline 3-ネチルペンテン-1 & 0.3 \\
\hline ペンタン類， ペンテン類 & 0.1 \\
\hline ヘキセン-1 & 0.0 \\
\hline
\end{tabular}

通常の Ziegler 触媒では 1-オレフィン以外のモノオレフィン は重合しないから，上記の5ちでは 3-メチルペンテン-1 が共重 合成分としてポリ(4-メチルペンテン-1)の中に入ってくる可能性 があるが,ここではこの点について考虑しない。

n-ヘプタン: 市販の 1 級品を濃硫酸とふりまぜ, 濃硫酸をとり かえて硫酸層が着色しなくなるまでくりかえしたのち水洗し, 塩 化カルシウムを加えて乾燥し, さらに上澄みに金属ナトリウムの 薄片を加えて 24 時間加熱還流したのち蒸留した。bp $96 \sim 98^{\circ} \mathrm{C}$

トリエチルアルミニウム: Texas Alkyl Co. 製のボンベ入り のものをそのまま精製 $n$-ヘプタンで希釈し $2 \mathrm{~mol}$ 溶液として用 いた。

四塩化チタン：日本試楽製 1 級品を窒素雾囲気中で常圧蒸留し た。bp 136〜 $136.5^{\circ} \mathrm{C}$ 。精製 $n$-ヘプタンで希釈し， $2 \mathrm{~mol}$ 溶液と して用いた。

\section{$2 \cdot 2$ 重合方法}

4-メチルペンテン-1 は bp $54^{\circ} \mathrm{C}$ であるから，この温度以下で あれば常圧で重合することができるが，ここでは重合条件の範囲 を広くとるため内容積 $100 \mathrm{~m} l$, 電磁カキマゼ式のステンレス製 オートクレーブを用いた。オートクレーブは内部を十分に乾燥し たのち, 窒素雾囲気中で所定の量の溶媒, 四塩化チタン溶液およ びトリェチルアルミニウム溶液を注射器を使ってこの順序で仕込

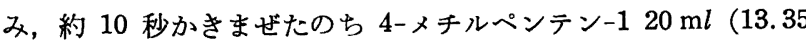
g) を注入する。このとき溶媒と触媒溶液との液量の和は $60 \mathrm{ml}$ になるようにした。オートクレーブを閉じてただちに一定の温度 に保持した油浴に浸して重合を開始する。オートクレーブ内部の 温度が一定になるまでに要する時間は重合温度 $40 \sim 105^{\circ} \mathrm{C}$ の範囲 ではいずれも 12 16 分であった。浴温度は $\pm 0.2^{\circ} \mathrm{C}$ の範囲で一 定に保った。重合時間終了後ただちに冷却し，オートクレーブ内 にメタノール $10 \mathrm{ml}$ を注入して触媒を分解し, さらに内容物を メタノールで洗い出して一夜放置したのち固体重合体を口別する。 次にこの重合体を $300 \mathrm{~m} l$ のメタノールに分散させて 3 時間加熱 還流してメタノールを口別する操作を 2 回くりかえし $60^{\circ} \mathrm{C}$ の真 空下で 24 時間乾燥した。な拉, 重合条件によって少量の液状重 合体が副生することがあるが，ここでは分離を行なわなかった。

\section{$2 \cdot 3$ 重合体の性侗の測定}

2.3.1 融点 ペネトロメーターを用い, 昇温速度 $1^{\circ} \mathrm{C} / \mathrm{min} て ゙$ 測定した。

2.3.2 比重 粉末重合体を减圧の窒素 $(<5 \mathrm{mmHg})$ 雾囲気中 で $280^{\circ} \mathrm{C} に 20$ 分間加熱溶融し，小型の円筒状に成形したのち， 再び减圧の窒素雾囲気中で $200^{\circ} \mathrm{C} に 2$ 時間保持して結晶化処理し たものを試料とした。比重の測定は $25^{\circ} \mathrm{C}$ でオストワルドの比重 計を用い，水一ェタノール系溶媒で浮沈法によって測定した。

2.3.3 溶液粘度 Fitz-Simons 型の粘度計を用いた。酸化防 止剤として 2,6-ジ-t-ブチル-4-メチルフェノール $1.0 \%$ を含む テトラリンを溶媒とし， $135 \pm 0.1^{\circ} \mathrm{C} て 0.2 \mathrm{~g} / 100 \mathrm{ml}$ の濃度に抏 ける比粘度を測定して $\eta_{\mathrm{sp}} / c$ であらわした。

$2 \cdot 3 \cdot 4$ 抽出減量 粉末 $1 \mathrm{~g}$ を隅川式抽出器を用いて 24 時間
抽出後, 乾燥して减量を測定し, さらに $n$-ヘプタンで 24 時間 抽出して同じ方法で減量を測定した。乾燥は $60^{\circ} \mathrm{C}$ ，高真空下で 24 時間行ない, 抽出減量は未抽出の重合体に対する重量比であ らわした。

\section{3 実験結果および考察}

重合宇験の大部分の結果を表 1 に示した。

\section{$3 \cdot 1$ 触媒成分のモル比の影響}

$\mathrm{TiCl}_{4}-\mathrm{R}_{3} \mathrm{Al}$ 系触媒で $\alpha$-オレフィンを重合するとき，一般に再 触媒成分の混合比によって重合活性が異なり, 活性が最大になる 混合比が存在することが知られている。 $\mathrm{TiCl}_{4}-\left(\mathrm{C}_{2} \mathrm{H}_{5}\right)_{3} \mathrm{Al}$ 系触媒

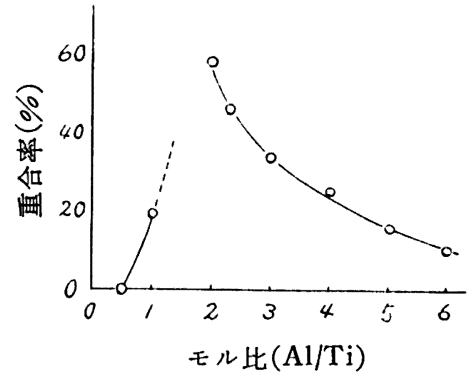

図 1 触媒成分のモル比と重合活性 幽星体: $13.35 \mathrm{~g}, n$-ヘプタン $: 60 \mathrm{~m} l, \mathrm{TiCl}_{4}$ ： $2.7 \mathrm{mmol}$, 温度: $60 \mathrm{C}$, 時間 $: 5 \mathrm{hr}$ で 4-メチルペンテン-1 を重合したときの結果を 図 1 に示した。四塩化チ タンの量を一定にしてト リェチルアルミニウムの 量を変えるとモル比 $(\mathrm{Al})$ Ti) 0.5 では固体重合体 はほとんど生成しない。 また，モル比 2 付近に重 合活性の最大值が存在す る。同じ触媒による $40^{\circ} \mathrm{C}$ での実験で Watt4) は重合活性のもっとも大きいモル比として 1.5 2 の值を得て括り，著者らの実験とは少し条件が異なるが この最大活性を示す触媒成分の混合比はほぼ一致している。

重合活性がモル比によって変化し最大活性を示す混合比が存在 する主要な理由としては次の二つが挙げられる。

(A） 四塩化チタンがアルキルアルミニウムによって還元され るとき，還元の程度は両成分の組成によって異なるわけで，還元 後のチタンの原子価が中間のある適当な值のときだけ活性である とすれば，モル比（Al/Ti）の值が過大かまたは過小のときには チタンの原子価分布が低原子価または高原子価にかたよって活性 が小さくなる。

（B）活性中心の構造が，固体のハロゲン化チタンの表面にア ルキルアルミニウム化合物が吸着されることによって形成され， 重合は八ロゲン化チタンの表面に吸着された単量体が前記の活性 中心と結合することによって扰こるとすれば，重合系のアルキル アルミニウムの濃度が大きすきると，単量体のハロゲン化チタン 表面への吸着が困難になって重合速度が低下すると考えられる。

この実験の範囲では（A)，(B) いずれが重要であるか明らかで ないが，(A)について，四塩化チタンとトリェチルアルミニウム とを混合したときのチタンの平均原子価については Kern ら9)の 報告がある。 $0^{\circ} \mathrm{C}$ で両成分を混合し， $25^{\circ} \mathrm{C} て ゙ 30$ 分放置したとき のデータでモル比 $(\mathrm{Al} / \mathrm{Ti}) 2.0$ のとき平均原子価は 2.5 程度で ある。著者らの実験ではこれより少し温度が高いので, 活性のも っとも大きい平均原子価は 2.5 よりもいく分小さいことが予想さ れる。Kern ら ${ }^{10)}$ は同じ触媒系でェチレンを重合するときチタン の平均原子価 2.5 のときに重合活性がもっとも大きいとて扣り， 著者らの結果とほぼ一致している。

9) R. J. Kern, H. G. Hurst, J. Polymer Sci. 44, 272(1960).

10) W. Kern, International Symposium on Macromolecular Chemistry, Paris (1963) における講演。 


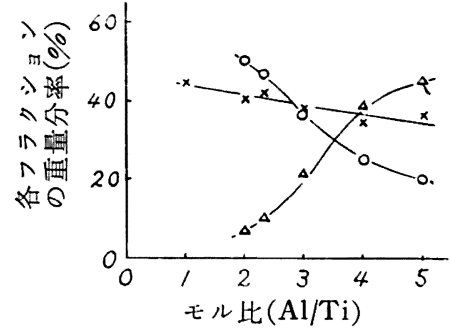

因 2 触媒成分のモル比と重合体の 溶解性

$$
\begin{aligned}
& O: \text { エーテル可溶部 } \\
& \triangle: \text { エーテル不溶, } n \text {-ヘプタン可溶部 } \\
& \times: n \text {-ヘプタン不溶部 }
\end{aligned}
$$

図 2 は重合体の抽出减

量を示した。エーテル可 溶の重合体はほとんどア タクチックな重合体と考 えられる粘着性のゴム状 物であるが，この部分は 触媒成分のモル比 (Al/ Ti）の增大とともに減少 している。モル比の小さ い場合には四塩化チタン とアルキルアルミニウム 化合物との反応によって 塩化アルミニウム，エチルアルミニウム二塩化物などのカチオン 重合の触媒となりうる化合物が重合系に存在する可能性が考えら れる。実際四塩化チタンやェチルアルミニウム二塩化物を単独で 触媒とするとき，4-メチルペンテン-1 の油状の低重合体の生成 がみとめられるので，上記のエーテル可溶の重合体は主としてカ チオン重合による生成物であると考えられる。また，エーテル不 溶で $n$-ヘプタンに可溶の重合体はエーテル可溶部と異なり粉末 状で結晶性をもつ重合体である。この部分はエーテル可溶部とは 逆にモル比 ( $\mathrm{Al} / \mathrm{Ti})$ が 2 以上のとき大きいほど多くなっている。 これはモル比の增大とともに重合体の平均分子量で低下寸るため, ある程度アイソタクチックな重合体も溶解性が増大して, $n$-ヘプ タン可溶部に含まれてくるためと考えられる。エーテル可溶部と n-ヘプタン可溶部の和をとると，大きな差ではないがモル比が 1 より大きいほど溶解性は大きくなっている。

表 1 によれば，溶液粘度すなわち重合体の平均分子量のもっと も大きいモル比は 3〜4であって, 重合活性のもっとも大きいモ ル比よりも大きいところにある。この前後で重合体の平均分子量 が低下するのは，抽出の結果と対比するとそれぞれェーテル可溶

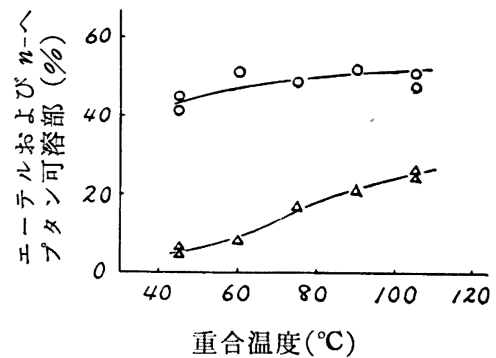

図 3 重合温度と重合体の溶解性の関係 $\mathrm{O}:$ エーテル可溶部 $\triangle:$ エーテル不浴, $n$ ーヘプタン可溶部
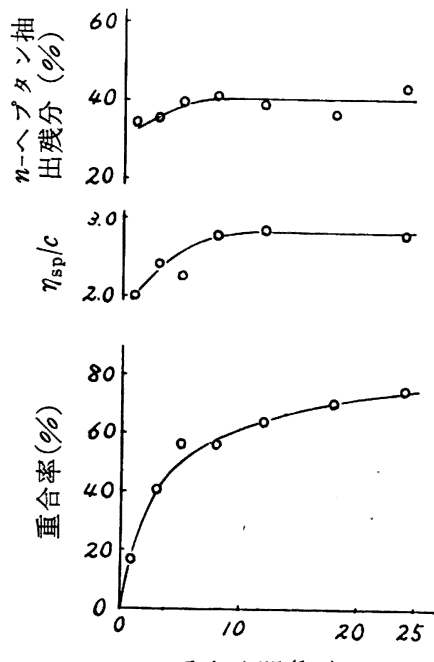

重合時間( $\mathrm{hr}$ )

図 4 重合時間の影響

单量体, $13.35 \mathrm{~g}, n$-ヘプタン $60 \mathrm{~m} l$ $\mathrm{TiCl}_{4}: 2.7 \mathrm{mmol},\left(\mathrm{C}_{2} \mathrm{H}_{5}\right)_{3} \mathrm{Al}: 5.4 \mathrm{mmol}$

\begin{tabular}{|c|c|c|c|c|c|c|c|c|c|c|c|c|}
\hline \multirow{2}{*}{$\begin{array}{l}\text { 寒 } \\
\text { 䂆 } \\
\text { 号 }\end{array}$} & \multirow{2}{*}{$\begin{array}{l}\text { 単量体 } \\
(\mathrm{g})\end{array}$} & \multicolumn{2}{|c|}{ 触＼cjkstart媒 } & \multirow[b]{2}{*}{$\begin{array}{l}\text { モル此 } \\
\mathrm{Al} / \mathrm{Ti}\end{array}$} & \multirow[b]{2}{*}{$\begin{array}{c}\text { 温 度 } \\
(\mathrm{C})\end{array}$} & \multirow{2}{*}{$\begin{array}{l}\text { 時 間 } \\
(\mathrm{hr} r)\end{array}$} & \multirow{2}{*}{$\begin{array}{l}\text { 重合体 } \\
\text { 収 量 } \\
\text { (g) }\end{array}$} & \multirow[b]{2}{*}{$\begin{array}{l}\text { 重合率 } \\
(\%)\end{array}$} & \multirow[b]{2}{*}{$\eta_{\mathrm{sp}} / c$} & \multicolumn{2}{|c|}{ 抽出娍量 } & \multirow[b]{2}{*}{$d_{4}^{25}$} \\
\hline & & $\begin{array}{c}\mathrm{TiCl}_{4} \\
(\mathrm{mmol})\end{array}$ & $\begin{array}{c}\left(\mathrm{C}_{2} \mathrm{H}_{5}\right)_{3} \\
(\mathrm{mmol})\end{array}$ & & & & & & & $\begin{array}{l}\text { エ- } \\
\text { テル } \\
(\%)\end{array}$ & $\begin{array}{c}n-\hat{n} \\
\text { タン* } \\
(\%) .\end{array}$ & \\
\hline 3 & 13. 35 & 5.4 & 16.2 & 3.0 & 60 & 5 & 9. 38 & 70.3 & 2.35 & 59.4 & 21.0 & 0.835 \\
\hline 4 & 13.35 & 2.7 & 8.1 & 3.0 & 60 & 5 & 4.52 & 33.9 & 3.07 & 36.8 & 21.1 & 0.837 \\
\hline 5 & 13.35 & 2.7 & 2.7 & 1.0 & 60 & 5 & 2. 63 & 19.6 & 2.23 & \multicolumn{2}{|c|}{55.8} & 0.836 \\
\hline 6 & 13. 35 & 2.7 & 5.4 & 2.0 & 60 & 5 & 7.73 & 58.2 & 2. 35 & 51.1 & 8.1 & 0.836 \\
\hline 11 & 13. 35 & 2.7 & 10.8 & 4.0 & 60 & 5 & 3.35 & 25.1 & 2.87 & 26.2 & 36.9 & - \\
\hline 12 & 13.35 & 2.7 & 1.35 & 0.5 & 60 & 5 & 徽量 & - & - & - & - & - \\
\hline 13 & 13. 35 & 2.7 & 5.4 & 2.0 & 75 & 5 & 7.12 & 53.4 & 2.04 & 48.8 & 16.3 & 0.835 \\
\hline 14 & 13.85 & 2.7 & 5.4 & 2.0 & 90 & 5 & 7. 31 & 54.8 & 1.57 & 51.8 & 20.7 & 0.834 \\
\hline 17 & 13. 35 & 2.7 & 13.5 & 5.0 & 60 & 5 & 2.13 & 16.0 & 2. 30 & 20.2 & 44.1 & - \\
\hline 18 & 13.35 & 2.7 & 6.0 & 2.3 & 60 & 5 & 6.18 & 46.3 & 2.78 & 48.0 & 9.3 & - \\
\hline 19 & 13.35 & 2.7 & 5.4 & 2.0 & 45 & 5 & 3.73 & 27.9 & 3.54 & 40.2 & 5.8 & 0.835 \\
\hline 20 & 13.35 & 2.7 & 5.4 & 2.0 & 45 & 5 & 3.45 & 25.8 & 3. 26 & 45.5 & 5.0 & 0.837 \\
\hline 21 & 13.35 & 2.7 & 5.4 & 2.0 & 105 & 5 & 6.63 & 49.7 & 1. 34 & 46.7 & 24.5 & 0.834 \\
\hline 22 & 13.35 & 2.7 & 5.4 & 2.0 & 105 & 5 & 4. 24 & 41.8 & 1.15 & 49.8 & 25.5 & 0.838 \\
\hline 23 & 13.35 & 2.7 & 5.4 & 2.0 & 60 & 24 & 10.01 & 75.0 & 2.93 & 48.0 & 7.6 & 0.838 \\
\hline 24 & 13.35 & 2.7 & 5.4 & 2.0 & 60 & 12 & 8.54 & 64.0 & 3.00 & 47.8 & 12.4 & 0.836 \\
\hline 25 & 13.35 & 2.7 & 5.4 & 2.0 & 60 & 8 & 7.58 & 56.8 & 2.90 & 47.8 & 10.5 & 0.835 \\
\hline 26 & 13.35 & 2.7 & 5.4 & 2.0 & 60 & 3 & 5.50 & 41.2 & 2.47 & 50.7 & 12.7 & 0.837 \\
\hline 27 & 13.35 & 2.7 & 5.4 & 2.0 & 60 & 36 & 10.49 & 78.6 & 2.74 & \multicolumn{2}{|c|}{50.7} & 0.835 \\
\hline 28 & 13.35 & 2.7 & 5.4 & 2.0 & 60 & 1 & 2.18 & 16.3 & 2.05 & 47.3 & 16.9 & 0.837 \\
\hline 29 & 13.35 & 2.7 & 16.2 & 6.0 & 60 & 5 & 1.40 & 10.5 & - & - & - & - \\
\hline 30 & 13.35 & 2.7 & 5.4 & 2.0 & 60 & 18 & 9.44 & 70.7 & - & - & - & - \\
\hline 31 & 13.35 & 2.7 & 5.4 & 2.0 & 45 & 12 & 4.93 & 36.9 & - & - & - & - \\
\hline 32 & 13.35 & 2.7 & 5.4 & 2.0 & 45 & 18 & 5.58 & 41.8 & - & - & - & - \\
\hline
\end{tabular}
重合嗢度: $60^{\circ} \mathrm{C}$

表 $1 \mathrm{TiCl}_{4}-\left(\mathrm{C}_{2} \mathrm{H}_{5}\right)_{3} \mathrm{Al}$ 系触媒による 4-メチルペンテン-1 の重合
部および n-ヘペタン 可溶部の寄与によるも のであろう。

$3 \cdot 2$ 重合温度の影響

$45 \sim 105^{\circ} \mathrm{C}$ の範囲で 重合温度を変えたとき に, 重合体の収量に及 ぼす効果はたとえば表 1 に示すよ 5 に $60^{\circ} \mathrm{C}$ 付近で重合率は最大と なり，これ以上温度が 高いほど固体重合体の 収量は低下寸る。高い 重合温度で重合活性が 小さくなる主要な原因 として, 触媒の変質と くにハロゲン化チタン が過度に還元される可 能性が重要であるかも しれない。同じ触媒系 でプロピレン11)，ブテ ンー112)などを重合する ときも $50^{\circ} \mathrm{C}$ 前後で重 合速度がもっとも大き くなるという報告があ り，著者らの 4-メチ ルペンテン-1 の結果 もこれとほぼ一致する。 つぎに生成重合体に ついて溶液粘度 $\eta_{\mathrm{sp}} / c$ は重合温度 $45 \sim 105^{\circ} \mathrm{C}$ の範囲で温度とと もに一様に低下している。抽出減量につ いてみると，図3に示したようにエーテ ル可溶部は重合温度の影響が小さく, $n$ ヘプタン可溶部は重合温度の影響が大き い。

\section{$3 \cdot 3$ 重合速度}

モル比 $(\mathrm{Al} / \mathrm{Ti})$ を 2 とし，60 合を行なうとき，重合率曲線は図 4 のと おりである。それぞれの重合時間に打け る重合体の溶液粘度と抽出残分の比率も 困 4 に示した。短い重合時間における重 合体の抽出减量が多いことは平均分子量 が小さいことによるものと思われる。

Natta ら ${ }^{13)}$ は $\mathrm{TiCl}_{4}-\left(\mathrm{C}_{2} \mathrm{H}_{5}\right)_{3} \mathrm{Al}$ 系触

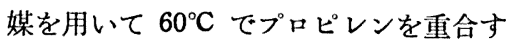

11) S. Kodama et al., J. Appl. Polymer Sci. 3, 20 (1960).

12) A.I. Medalia et al., J. Polymer Sci. 41, 241 (1959).

13) G. Natta et al., Gazz.chim.ital. 87, 549 (1957). 


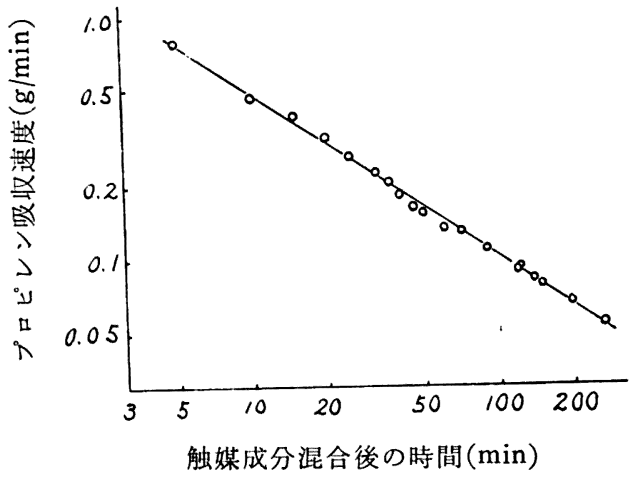

図 5 触媒成分混合後の活性低下に関する Natta $5^{13)}$ のデータのプロット

るとき，触媒の重合活性は両成分を混合した後の時間ともに急速 に低下し，この活性低下は系にプロピレンが存在するときもしな いときも同様に扣こることを認めた。この Natta らのデータを 重合活性と触媒成分の混合後の時間とを両軸にとって両対数方眼 紙にプロットすると図 5 のような直線関係が得られ, 直線の傾斜 から次の関係が得られる。

$$
\left[\mathrm{C}^{*}\right]=k_{\mathrm{c}} t^{-2 / 3}
$$

ここに [C*]：プロピレンの重合に有効な活性点の濃度

$$
\begin{aligned}
t & \text { : 触媒成分混合後の時間 } \\
k_{\mathrm{c}} & \text { : 定数 }
\end{aligned}
$$

この式の反応機㮖的な意味はさて招き, $\mathrm{TiCl}_{4}-\left(\mathrm{C}_{2} \mathrm{H}_{5}\right)_{3} \mathrm{Al}$ 系触 媒による 4-メチルペンテン-1 の重合の場合にも活性点の数が式 （1）にしたがって時間的に減少し，また重合速度は単量体濃度に 対して 1 次であるとすれば, 次の式が成立つ。

$$
-\frac{\mathrm{d}[\mathrm{M}]}{\mathrm{d} t}=k_{\mathrm{p}}\left[\mathrm{C}^{*}\right][\mathrm{M}]
$$

[M] : 単量体䟴度, $k_{\mathrm{p}}$ : 速度定数

式（1）牤よび（2）から

$$
\begin{gathered}
-\frac{\mathrm{d}[\mathrm{M}]}{\mathrm{d} t}=k_{\mathrm{p}} k_{\mathrm{c}} t^{-2 / 3}[\mathrm{M}] \\
-\ln [\mathrm{M}]=3 k_{\mathrm{p}} k_{\mathrm{c}} t^{1 / 3}[\mathrm{M}]+c
\end{gathered}
$$

$t=t_{0}$ のとき $[\mathrm{M}]=[\mathrm{M}]_{0}$, また $3 k_{\mathrm{p}} k_{\mathrm{c}}=k$ とおけけば

$$
-\ln \frac{[\mathrm{M}]_{0}}{[\mathrm{M}]}=k\left(t_{0}{ }^{1 / 3}-t^{1 / 3}\right)
$$

$t_{0}:$ 触媒成分混合後単量体を入れるまでの時間

著者らの奏験では触媒の二つの成分と単量体とを混合してから 混合物の温度を室温から $60^{\circ} \mathrm{C}$ までげているので, この昇温の 途中は複雑であるが, この点を無視し, $\log \left\{[\mathrm{M}] /[\mathrm{M}]_{0}\right\}-t^{1 / 3}$ の 関係をプロットすると図6のよ5に直線関係が得られる。したが

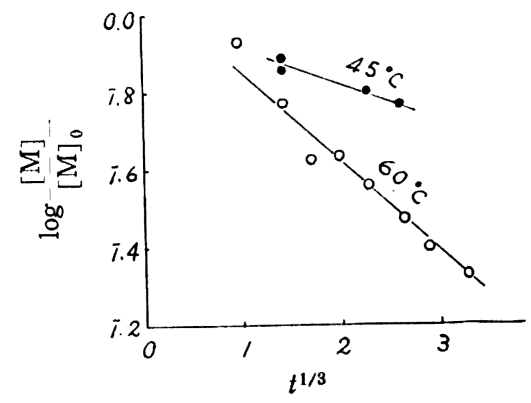

図 6 重合速度の実験値のプロット
って, 重合速度は単量体濃度の 1 次に比例し, 触媒の活性点の濃 度は触媒成分混合後の時間の $-2 / 3$ 次に比例するとして得られた

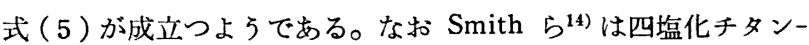
トリアルキアルミニウム系触媒で $160^{\circ} \mathrm{C}$ においてェチレンを重合 するとき, 触媒の活性低下の速度は触媒濃度の 2 乗に比例すると 述べており，上にのべた Natta らの結果とは異なるが，著者ら の実験では，Natta らの結果を用いて誘導した速度式が実験値と よく一致した。これは, 著者らの実験条件が Natta らの条件に 近くSmith らの条件とは著しく異なるためであろう。なお，四 6 の直線の傾斜から $k$ を求め, 見掛けの活性化エネルギーを求 めると䄪 $10 \mathrm{kcal} / \mathrm{mol}$ となった。

\section{4 触媒熱成の影䈍}

前に述べたよ5に, $\mathrm{TiCl}_{4}-\left(\mathrm{C}_{2} \mathrm{H}_{5}\right)_{3} \mathrm{Al}$ 系触媒は不安定で $60^{\circ} \mathrm{C}$

\begin{tabular}{|c|c|c|c|c|c|}
\hline \multirow[b]{2}{*}{ 实験番号 } & \multicolumn{2}{|c|}{ 触媒熟成条件 } & \multirow{2}{*}{$\begin{array}{c}\text { 単量 } \\
\text { (g) }\end{array}$} & \multirow{2}{*}{$\begin{array}{c}\text { 固体重盒 } \\
\text { 悔 } \\
(\mathbf{g})\end{array}$} & \multirow{2}{*}{$\begin{array}{l}\text { 収 率 } \\
(\%)\end{array}$} \\
\hline & $\overbrace{(\text { 温 }}^{(C)}$ & $\begin{array}{c}\text { 時 閏 } \\
\text { (hr) }\end{array}$ & & & \\
\hline 6 & - & 0 & 13.35 & 7.77 & 58.2 \\
\hline 37 & 30 & 2.0 & 13.35 & 6.25 & 46.8 \\
\hline 39 & 30 & 0.5 & 13.35 & 6.65 & 49.8 \\
\hline 40 & 30 & 1.0 & 13. 35 & 6.38 & 47.8 \\
\hline
\end{tabular}
くらいで放置するとき重合活性が急速に低下する。ここでは 30 ${ }^{\circ} \mathrm{C}$ で触媒を熟成したときの活性の変化をしらべた。この結果を 表 2 に示す。 2 時間までの熟成では活性の低下はわずかである。

表 2 触媒熟成時間の影響

n-ヘプタン: $60 \mathrm{ml}, \mathrm{TiCl}_{4}: 2.7 \mathrm{mmol},\left(\mathrm{C}_{2} \mathrm{H}_{5}\right)_{3} \mathrm{Al}: 5.4 \mathrm{mmol}$ 重合温度: 600, 時間 $: 5 \mathrm{hr}$

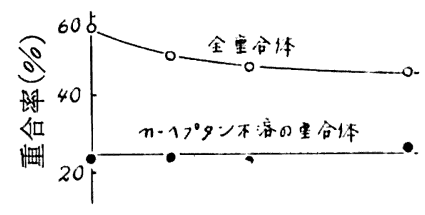

因 7 に示民たように熟成 した触媒によって得られ る重合体は熟成しない触 媒を用いた場合にくらべ て抽出減量が少なく, 溶 液粘度は大きくなってい る。溶媒抽出後の重合体 についてみると重合体収 量は熟成時間によらずほ ぼ一定であり，溶液粘度 もほぼ同じになっている ことから，触媒を熟成す ることによって結晶性の よくない，また分子量の 小さい重合体を生成する ような活性点が減少し, $n$-ヘプタン不溶の高分子 量の重合体を生成するよ らな活性点はあまり変化 を受けないと推定される。

\section{5 重合体の性}

表 1 に示したと拈り得られた重合体の比重は $0.834 \sim 0.838$ の 範囲であり, 重合条件との相関関係は明膫ではなかった。このこ とはすでに Griffith ら ${ }^{15)}$ が指摘しているようにポリ(4-メチルペ

14) W.E.Smith, R.G.Zelmer, J. Polymer Sci. Part A, 1, 2587 (1963).

15) J. H. Griffith, B. G. Rånby, ibid. 44, 369 (1960). 
表 3 ポリ 4 -メチルペンテン-1)の骶点

\begin{tabular}{|c|c|c|}
\hline 重合番号 & 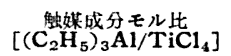 & ペネトロメーター蠤点 \\
\hline 3 & 1 & 221 \\
\hline 4 & 2 & 217.2 \\
\hline 18 & 2.3 & 212 \\
\hline 2 & 3 & 211.8 \\
\hline 9 & 4 & 214.7 \\
\hline 15 & 5 & 209.8 \\
\hline
\end{tabular}

ンテン-1）の結晶部と非晶部の比重が常温付近ではきわめて近似 しており, 結晶化度による比重の差が非常に小さくなるためであ ろ5。
二, 三の試料についての融点を表 3 に示した，触媒成分の組成 $(\mathrm{Al} / \mathrm{Ti})$ と相関関係が認められる。すでに報告されているポリ (4 -メチルペンテン-1) の融点は $200 \sim 205^{\circ} \mathrm{C}^{3)}, 235^{\circ} \mathrm{C}^{1,6,16)}, 240$ ${ }^{\circ} \mathrm{C}^{7)}, 250^{\circ} \mathrm{C}^{15)}$ などの值があり，著者らの測定値は Natta らのデ 一ダ)を除くと少し低いが，これが測定法の差によるものか，ま たは重合体の結晶性の差によるものがいまのところ明らかでない。

(本報の内容の大部分は昭和 38 年 4 月の日本化学会第 16 年 会で発表した。)

本研究の発表を許可された取楴役小林治男博士に感謝します。

16) F. P. Reding, J. Poymer Sci. 21, 547 (1956).

\title{
プロピレンスルフィトの重合
}

(昭 和 38 年 12 月 10 日受 理)

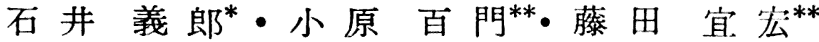

\begin{abstract}
プロピレンスルフィドの高重合体を得る目的で種々の有機金属化合物を触媒として 0 ～ $80^{\circ} \mathrm{C}$ で重合性をしらべた。金 属アルコキシドはほとんど触媒活性は認められないが, $\mathrm{Na}, \mathrm{Cd}, \mathrm{Zn}, \mathrm{Cu}$ のメルカプチド, $\mathrm{AlEt}_{3}, \mathrm{Et}_{2} \mathrm{AlCl}$ および $\mathrm{ZnEt}_{2}$ は高収率でポリマーを与えるがポリマーの重合度は比較的低い。Fe または Co のメルカプチドと $\mathrm{AlEt}_{3}$ の組合せ触媒系 は高重合度のポリマーを与え,ポリマーの分子量は 2 成分のモル比で支配される。結果より重合機構を推定した。
\end{abstract}

\section{- 1 腥 言}

1 個のヘテロ原子を含む三員環化合物の開環重合に関しては, エポキシドについて最む広く研究がなされてきているが,イミン, さらにスルフィドに関するものは比較的少ない。

プロピレンスルフィドはェチレンスルフィドに此べてかなり安 定なことが知られている1)。従来, 触媒として ethanolic sodium ethoxide $^{2)}$, 表面がカセイソーダで椱われた金属ナトリウム3)を 用いたプロピレンスルフィドの重合が報告されているが，これら はいずれも比較的重合度の低いポリマーしか得られていない。小 林ら")は II -b 族元素の塩類特にカドミウムのケイ酸塩が高分子 量のポリマーを与えることを明らかにした。

著者らはプロピレンスルフィドの高分子量ポリマーを得る目的 で, 種々の金属アルコキシド, 金属メルカプチドおよび $\mathrm{AlEt}_{3}$, $\mathrm{Et}_{2} \mathrm{AlCl}, \mathrm{ZnEt}_{2}$ 等を用いてプロピレンスルフィドの重合性を検 討した。

\section{2 実呀}

\section{$2 \cdot 1$ 試 菜}

2.1・1 モノマー D.R.P. 636,708 の方法に準じてプロピレ ンオキシドとロダンカリウムの反応により調製した。無水塩化カ

* 名古屋大学工学部応用化学科：名古屋市千種区不老町.

** 東洋曹達工業株式会社研究部：山口県都濃郡南陽町富田 4560.

1) M. Delépine, P. Jaffeux, Compt.rend. 172, 158(1921); Chem. Abst. 15, 1283 (1921).

2) C. S. Marvel, E. D. Weil, J. Am. Chem. Soc. 76, 61 (1954).

3) P. B. 121, 796, June 1956.

4) 小林, 森脇, 第 11 回高分子年次大会要旨集.
ルシウムで脱水後分留し，さらに水素化カルシウムで脱水後蒸留 して bp 74.5〜 75C のものを用いた。

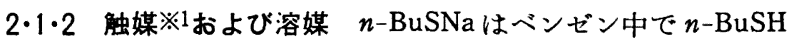
と金属ナトリウムとの反応で得た。 $n$-BuSCu は $n$-BuSH と $\mathrm{Cu}$ $(\mathrm{AcO})_{2}$ から Duncan 5 $5^{5)}$ の方法で, $(n-\mathrm{BuS})_{2} \mathrm{Zn}$ も同法に準じ て調製した。鉄、コバルト、ニッケルのメルカプチドはClassone の方法6) に準じて各金属の塩化物 または酷酸塩を $n$-BuSH と反 応させて得た。 $n$ - $\mathrm{BuSCdCl}$ は土タノール中で $n$ - $\mathrm{BuSH}$ と $\mathrm{CdCl}_{2}$ とから得た。 $\mathrm{AlEt}_{3}$ および $\mathrm{Et}_{2} \mathrm{AlCl}$ は市販品を䄪 $20 \%$ ベンゼン 溶夜として用いた。触媒の取扱いはすべて乾燥窒素ガス気流中で 行なった。

溶媒はいずれも常法により十分脱水精製して用いた。

\section{$2 \cdot 2$ 重合方法およびポリマーの処理}

乾燥窒素ガスにて十分置換したガラス製耐圧管中に $-40^{\circ} \mathrm{C} て ゙$ 触媒, 溶媒, モノマーの順に添加し所定温度で所定時間静置重合 を行なった。所定時間後開封し少量の塩酸酸性メタノールを加え て重合を停止させ，ポリマーをベンゼンに溶かし遠心分離法にて 触媒残分を除去したのち，多量の石油エーテル中で沈县させる方 法でポリマーを精製した。 $50^{\circ} \mathrm{C}$ 減圧下で溶剤を除去し恒量にな った時の重量よりポリマー収率を求めた。

\section{$2 \cdot 3$ ポリマー性状の検討}

ポリマーの粘度はベンゼン中 $30 \pm 0.02^{\circ} \mathrm{C}$ でオストワルド粘度 計で溶液粘度を測定し，濃度と比粘度から還元粘度を求めた。固 有粘度は外插法によった。ポリマー濃度は $0.1 \sim 1.0 \mathrm{~g} / \mathrm{d} l$ である。

※1 金属アルキシド拉よびその部分的加水分解物は名古屋大学 工学部工業有機化学教室鹪見 茂氏より, $\mathrm{ZnEt}_{2}$ は東洋曹 達工業株式会社岡崎 燕氏より頂いた。記して感謝します。

5) W.E. Duncan et al., Ind.Eng. Chem. 28, 381 (1931).

6) P. Classone. J. Prakt. Chem. [2] 15, 193 (1877). 